\title{
THE FACTORS OF INFLUENCE ON THE QUALITY OF TOURIST SERVICES IN THE REGION
}

\author{
Liudmyla Matviichuk ${ }^{1}$, Iryna Karpiuk ${ }^{2}$
}

Received: 2021-03-09

Accepted: 2021-04-19

DOI: http://doi.org/10.46489/gpj.2021-1-1-9

\begin{abstract}
The article considers the main directions of the quality assurance of tourist services at the region's level. We proved that the qualitative development of tourist regions requires changes in the structure of production of a tourist product and significant changes in the organization of its production. The current state of services in the regions of Ukraine is under the impact of a significant number of factors. The main determinants are the "COVID19" pandemic spread, increasing number of natural and anthropogenic disasters, the spread of terrorism and hostilities, et cetera. All these factors hinder the development of services. However, to promote domestic tourism as one of the areas of service in Ukraine, the pandemic was more resultative than joined industry reforms.

Today, there is an increase in domestic tourists, and the tourism industry could get significant profits from the surge of domestic tourism. However, most of these trips are selforganized. In addition, most current tourists are looking for new experiences that allow relaxing, see and hear, and feel, taste, try, and learn about the area through cuisine, traditions, and ceremonies to take part in them. Therefore, we tried to substantiate new ways to improve the quality of service in the regions of Ukraine. The analysis of factors influencing the quality of regional tourist services is essential for the future development.
\end{abstract}

Keywords: tourist service, region, quality assurance, tourism, development, pandemic influence.

\footnotetext{
${ }^{1}$ Liudmyla Matviichuk, Doctor of Economic Sciences, Professor, Lesya Ukrainka Volyn National University, Voli str., 13, 43025 Lutsk, Ukraine, ORCID: https://orcid.org/0000-0003-1694-6178.

${ }^{2}$ Iryna Karpiuk, Postgraduate student, Lutsk National Technical University, Lvivska st., 75, 43018 Lutsk, Ukraine, ORCID: https://orcid.org/0000-0002-9887-1802.
} 


\section{ВСТУП}

Сьогодні

спостерігається збільшення кількості внутрішніх туристів, а суб'єкти туристичної галузі, могли б заробити на збыльшений попит на внутрішній туризм, однак більше $50 \%$ таких подорожей люди організовують самостійно. Вимоги сучасних туристів змінюються, вони шукають нових вражень, які дозволять не тільки відпочивати, бачити та чути, але й відчути, спробувати, продегустувати та відвідати місцеву кухню, традиції та обряди.

Для досягнення вище сказаного, необхідне проведення досліджень щодо пошуку нових напрямів підвищення рівня якості обслуговування сфери послуг в регіонах України. Тому, вивчення та аналіз факторів впливу на якість туристичних послуг регіонів мають вагоме значення для перспективного майбутнього розвитку регіонів.

Значним внеском у дослідження якості туристичних послуг в регіоні можна виділити таких вчених, як: Kudla N.Ye. (2012), Kotler F. (1998), Azghaldov H.H. (1994), Lazibat T. (2005), Konakh S. S. (2015), Dyshko O.L. (2016), Tkachenko T.I. (2009) та інших. Наукові праці які присвячені якості туристичних послуг мають аналітичне спрамування та присвячені загальним характеристикам, які не враховують сучасні фактори впливу.

\section{РЕЗУЛЬТАТИ}

За твердженням всесвітньо відомого класика-маркетолога Ф. Котлера, «аналіз і визначення ринку дає сферу, в якій буде розвиватися конкуренція» (Kotler F., 1998). Отже, потрібно просвести якісні маркетингові дослідження.

Функціонування ринку туристичних послуг на рівні регіону визначають дві групи факторів: фактори попиту i фактори пропозиції. У відповідності до кейнсіанської теорії, попит відіграє провідну роль у формуванні ринку, адже приносити прибуток може лише той товар чи послуга, яка користується попитом.

Функціонування ринку туристичних послуг на рівні регіону можна звести до примітивної взаємодії попиту та пропозиції, коли в разі недостатньої пропозиції ціни зростають i забезпечують виробнику туристичних послуг рентабельне їх виробництво, тоді як пожвавлення виробництва збільшує обсяги пропозиції, внаслідок чого ціни на туристичні послуги знижуються. Виходячи 3 цього, формування регіонального ринку туристичних послуг залежить, у першу чергу, від забезпечення платоспроможного попиту на таку продукцію. Аналіз факторів впливу на формування якісного регіонального ринку туристичних послуг на основі попиту та пропозиції представлено в таблиці 1.

Сьогодні можна спостерігати суттєві відмінності в туристичному розвитку регіонів України, кожен з яких володіє вираженою специфікою. Тому, розгляд факторів впливу на формування та розвиток регіональних ринків сфери послуг на регіональному рівні $\epsilon$ актуальним. Проведений аналіз даної проблеми дозволяє визначити ключові фактори формування ринку туристичних послуг на рівні регіону. Загалом, вплив таких факторів на формування регіонального ринку туристичних послуг можна систематизувати у вигляді рисунку 1.

Так, на регіональний ринок туристичних послуг впливають декілька груп факторів. Чисельність населення в регіоні та його платоспроможність $€$ одним 3 найвпливовіших факторів, які формують попит. Цей фактор тісно пов'язується із загальним рівнем доходів населення. Він утворює попит на туристичні послуги і розвиває його. 
Фактори впливу на формування якісного регіонального ринку

Таблиця 1.

сфери послуг

\begin{tabular}{|c|c|}
\hline \multicolumn{2}{|c|}{ Формування ринку сфери послуг } \\
\hline Фактори попиту & Фактори пропозиції \\
\hline $\begin{array}{l}\text { - складна епідеміологічна ситуація; } \\
\text { - незначний асортимент сфери послуг; } \\
\text { - низька купівельна спроможність населення; } \\
\text { - відсутність державної підтримки туристичної } \\
\text { галузі; } \\
\text { - брак довіри до гарантії якості сфери послуг; } \\
\text { - низький рівень культури відпочинку; } \\
\text { - недостатній рівень популяризації атрактивних } \\
\text { об'єктів в регіонах; } \\
\text { - зменшення кількості населення в регіонах } \\
\text { країни. }\end{array}$ & 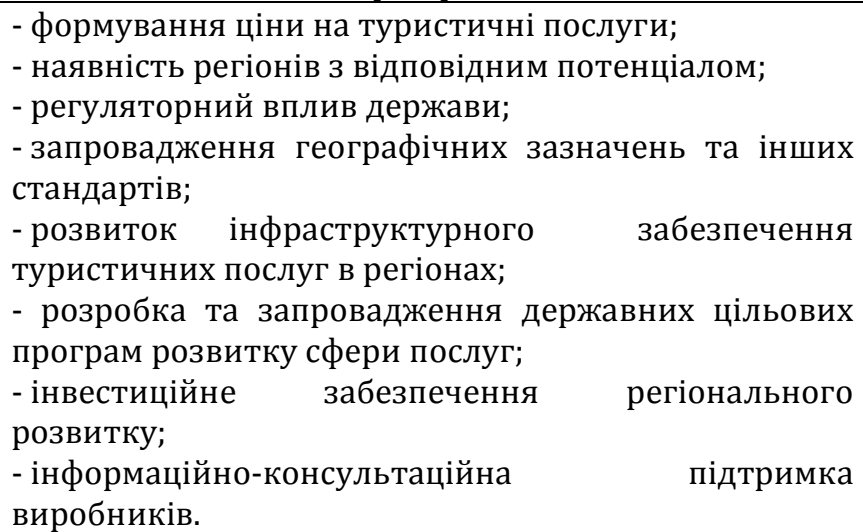 \\
\hline
\end{tabular}

Систематизовано автором

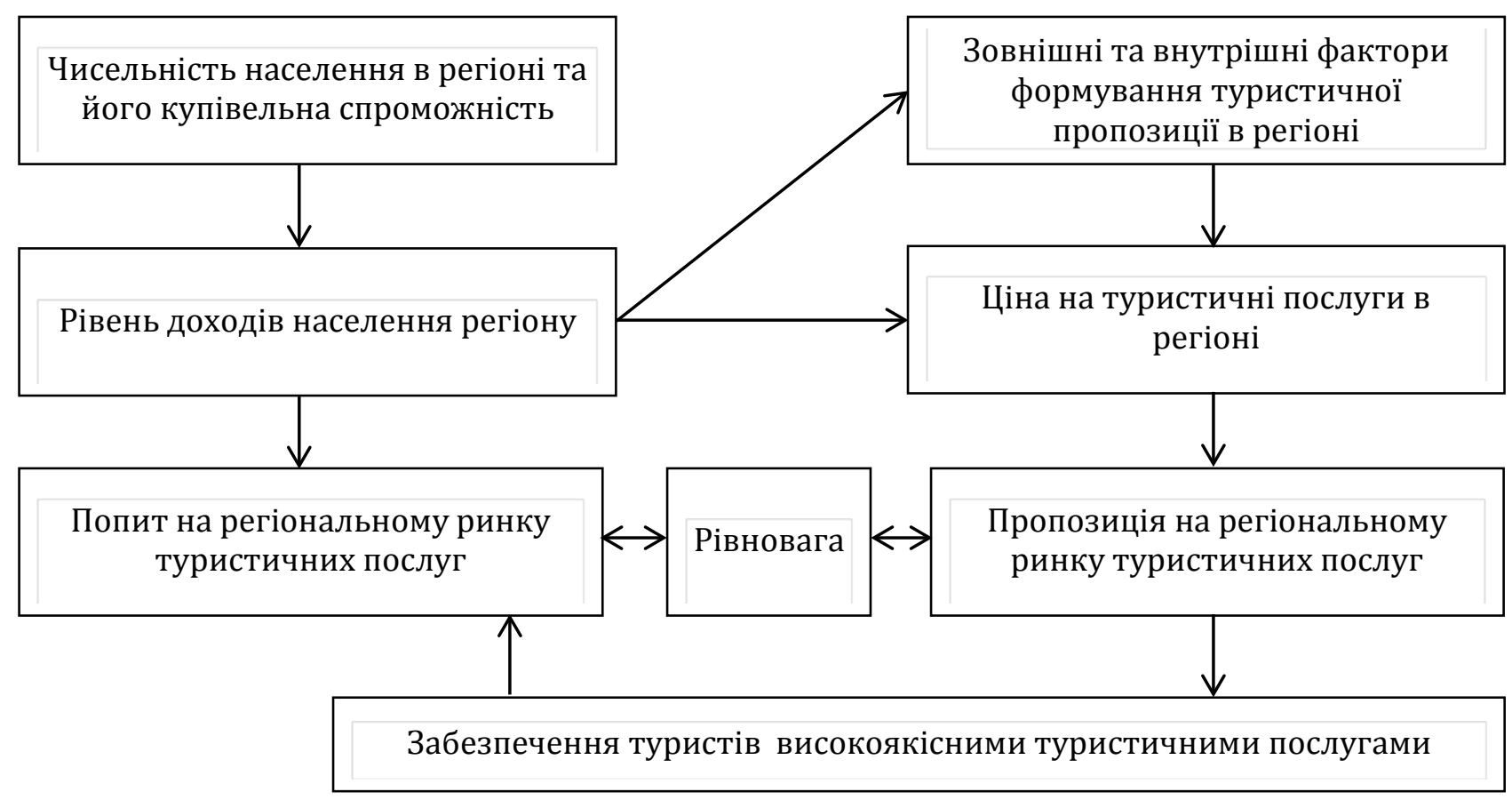

Рис. 1. Ключові фактори формування регіонального ринку туристичних послуг

Інший фактор - формується суб'єктами туристичної діяльності, де виробляється туристична пропозиція. Тут, параметри виробництва формуються в залежності від зовнішніх та внутрішніх факторів діяльності суб'єктів туристичної галузі регіону. Вони проявляються в основному через встановлення ціни на туристичну продукцію. В сукупності обсяги туристичних пропозицій разом із параметрами ціни та якості утворюють загальну пропозицію на регіональному ринку туристичних послуг.

Враховуючи те, що регіональний ринок туристичних послуг є складною та специфічною системою, яка складається 3 численних елементів і взаємозв'язків між ними, вивчення рівня якості цього ринку потребує всебічного аналізу ряду факторів (табл. 2), що визначають його напрям формування пропозиції регіонального 
ринку, а також виявлення особливостей ринкових взаємодій між суб'єктами туристичної діяльності.

Таблиця 2

Фактори впливу на якість туристичних послуг (систематизовано автором)

\begin{tabular}{|c|c|}
\hline Фактор & Вплив \\
\hline $\begin{array}{c}\text { Економічне } \\
\text { зростання регіону }\end{array}$ & $\begin{array}{l}\text { - наявність та структурний склад туристичних ресурсів (природних, } \\
\text { історико-культурних, економічних тощо); } \\
\text { - розвиток технологій та технічного оснащення туристичного сектору в } \\
\text { регіоні; } \\
\text { - наявність центрів туристичної інформації та послуг для формування } \\
\text { внутрішніх та міжрегіональних туристичних пропозицій; } \\
\text { - економіко-географічні переваги регіону (близькість до кордону); } \\
\text { - інвестиційна привабливість регіону. }\end{array}$ \\
\hline Обсяг попиту & $\begin{array}{l}\text { - рівень цін на туристичні послуги в регіоні; } \\
\text { - величина заробітньої плати і доходів потенційних туристів; } \\
\text { - чисельність постійних туристів регіону; } \\
\text { - структура споживчих потреб в туристичній продукції; } \\
\text { - соціальні та економічні очікування туристів регіону; } \\
\text { - регіональна культура туристичного споживання (дотримання постів, } \\
\text { смаки та уподобання мешканців, їх стереотипи); } \\
\text { - ефективність маркетингових інструментів, які використовуються для } \\
\text { популяризації туристичних послуг регіону. }\end{array}$ \\
\hline $\begin{array}{c}\text { Співвідношення } \\
\text { попиту і пропозиції }\end{array}$ & $\begin{array}{l}\text { - формування ціни реалізації; } \\
\text { - методи поширення інформації про туристичні пропозиції регіону; } \\
\text { - методи стимулювання виробників і споживачів туристичних послуг. }\end{array}$ \\
\hline $\begin{array}{c}\text { Органи } \\
\text { загальнодержавного } \\
\text { та регіонального } \\
\text { управління }\end{array}$ & $\begin{array}{l}\text { - вплив державних інституцій на формування структури ринку } \\
\text { туристичних послуг регіону; } \\
\text { - ступінь інституційної підтримки суб'єктів туризму в регіоні; } \\
\text { - сучасна нормативно-правова база щодо стимулювання створення } \\
\text { нових малих та середніх підприємств що формують туристичну } \\
\text { пропозицію, контроль за ціноутворенням тощо. }\end{array}$ \\
\hline $\begin{array}{c}\text { Фактор непрямого } \\
\text { впливу }\end{array}$ & $\begin{array}{l}\text { - соціальне, політичне, культурне середовище регіону; } \\
\text { - соціально-психологічний } \quad \text { стан } \quad \text { населення регіону (потенційних } \\
\text { туристів). }\end{array}$ \\
\hline
\end{tabular}

Формування

пропозиції туристичних послуг на рівні регіону пов'язано з особливостями регіональної туристичної продукції, що в свою чергу вимагає чіткого дотримання певних господарських та організаційних умов.

Можна також визначити низку факторів, що впливають на поведінку споживачів, їхнє ставлення до певного виду туристичної послуги та мотиви здійснення покупки. Основні фактори впливу на формування попиту та поведінку туристів на регіональному ринку туристичних послуг: вплив комплексу маркетингу, соціокультурні фактори, фактори ситуаційного впливу, психологічні фактори, особистісні фактори. Серед зазначених п'яти груп факторів чотири 3 них господарюючі суб'єкти туристичного ринку не можуть контролювати, а саме: психологічні; соціокультурні; особистісні; ситуаційного впливу. Група факторів комплексу маркетингу як сукупності маркетингових інструментів (послуга, ціна, розподіл, просування), суму яких господарюючі суб'єкти використовують 3 метою позитивного впливу на цільовий сегмент туристичного ринку, повною мірою має контролювати менеджмент цих суб'єктів.

Так, для того щоб підвищувати рівень якості туристичних послуг в регіоні, а також впроваджувати кращі 
світові стандарти якості в діяльність господарюючих суб’єктів туризму в регіоні, потрібно досить ретельно вивчати та оцінювати вподобання своїх цільових сегментів туристичного ринку.

Варто також зазначити, що характерною рисою сучасного ринку туристичних послуг на рівні регіону поки що $\epsilon$ незначна привабливість та низька окупність інвестицій, потреба у значних їх обсягах і складність щодо впровадження інновацій. Мають місце суттєві коливання цін на туристичні послуги, їх залежність від сезонності, часу та місця реалізації, навіть незалежно від туристичних агентів. На рівень якості туристичних послуг впливає також низький рівень освітньокваліфікаційної підготовки і консерватизм надавачів туристичних послуг, що стримує впровадження нових методів організації виробництва й управління, адаптацію до змін ринкових умов господарювання у зв'язку 3 поширенням пандемії «COVID-19».

Таким чином, на сучасному етапі розвитку, основними діючими факторами якості туристичних послуг на рівні регіону $є$ як ті , що сприяють розвитку ринку туристичних послуг, так ті, що його гальмують.

До основних стримуючих якість факторів розвитку регіонального ринку туристичних послуг, на нашу думку, можна віднести організаційноекономічні, адміністративні, технікоекономічні, демографічні, регіональні, соціальні:

- стрімке поширення пандемії «COVID-19» в усіх регіонах країни здійснює найбільший деструктивний вплив на якість туристичних послуг та визначає необхідність переформатування усієї туристичної галузі. На нашу думку, якісний розвиток туристичних послуг в регіоні можливий за рахунок запровадження заходів 3 мінімізації наслідків пандемії «COVID19», серед яких основними $\epsilon$ впровадження інформаційновіртуальних туристичних ресурсів, а також обов'язкових заходів із захисту здоров'я й безпеки туристів. Віртуальна відвідуваність може стати одним 3 напрямів як порятунку туристичної сфери регіонів так і інструментом підвищення рівня якості туристичних послуг;

- відсутність капіталу - ще одна серйозна перешкода для надання якісних туристичних послуг малими та середніми підприємництва туристичної сфери у регіоні, це стосується як браку капіталу для започаткування бізнесу на основі світових стандартів якості, так і його модернізації. Найбільші труднощі пов'язані саме з початком господарської діяльності відповідно стандартів якості. Впровадження нових або модернізованих технологій, таких як купівля ліцензії, ноу-хау, сертифікація, пов'язане 3 високою вартістю й потребує наукових досліджень і розробок;

- відсутність кваліфікованих кадрів - ця проблема існує в менталітеті населення, підкріплюється недостатнім рівнем освіти, недосконалим володінням міжнародних мов, незначно кількістю ідей та ініціатив. У зв'язку з переважанням апатії та очікування, які існують в регіонах країни, необхідна діяльність, спрямована на пробудження економічної активності;

Подолання наявних деструктивних факторів має декларуватися в державних i місцевих програмах розвитку, що дозволить ефективно реагувати на посилення дії зазначених факторів.

На сучасному етапі розвитку туристичних послуг в регіоні ще не доведено безпосередній характер залежності рівня розвитку туризму від ефективності управління та використання новітніх підприємницьких технологій в цій сфері економіки; не повністю виявлено вплив 
механізмів управління та регулювання на зростання соціальної та економічної ефективності туристичної галузі, що $\epsilon$ важливим елементом у процесі входження нашої держави на світовий туристичний ринок.

Об'єктом управління в туризмі $\epsilon$ туристичні фірми, процес туристичного обслуговування громадян у регіоні, а також колектив, персонал, сукупність соціально-економічних, правових, моральних і інших відносин, що виникають між людьми в процесі виробництва і обігу туристського продукту. При цьому важливо враховувати, що процес соціального управління в сфері туризму за своєю природою торкається надзвичайно широкого кола відносин між людьми в сфері їхнього виробництва і обігу. Наприклад, при розробці і реалізації туристичного продукту цілеспрямовано взаємодіють працівники готельного i ресторанного господарства, транспорту, культурно-видовищних і інших галузей туристичного комплексу, як вітчизняних, так i закордонних партнерів.

Туризм може бути об'єктом управління на будь-якому рівні, у тому числі на рівні регіональному. Якщо $\epsilon$ об'єкт управління, то $\epsilon$ i суб'єкт управління. Суб'єктом соціального управління може бути управлінська система; організаційно оформлені спілки людей, наділені функціями зі здійснення управлінського впливу, специфіка якого визначається характером його впливу, він спрямований на людей і виконується людьми. Завдання полягає в узгодженні, гармонізації інтересів окремої спільноти, соціальних груп, індивідів у процесі життєдіяльності суспільства, реалізації їхніх цілей.

Для ефективної підвищення рівня якості туристичних послуг в регіоні доцільно дотримуватись принципів ефективного управління якістю, здорової конкуренції, доброчесного ведення бізнесу та постійного удосконалення, підвищення кваліфікації та самоосвіти (рисунок 2).

В основу механізмів підвищення якості туристичних послуг в регіоні покладено такий алгоритм дій який складається 3 комплексності туристичної послуги, якості праці персоналу, якості послуги, якість туристичної інфраструктури регіону, матеріально-технічної бази, де відбувається процес обслуговування. В основу такого механізму нами покладено такі визначені критерії якості туристичної послуги: відчутність, безпека, комфорт, компетентність, корисність та комплексність.

Розроблена модель управління якістю сучасних туристичних послуг в Україні, що на відміну від існуючих, передбачає визначення пріоритетів розвитку та стратегічних цілей переходу на інноваційну модель розвитку регіону, застосування систематизованих інструментів реалізації зазначеного механізму, що дозволить забезпечити дієву взаємодію суб'єктів інноваційної діяльності регіону, формування сприятливого інституційного середовища регіону, яке б стимулювало розвиток туристичних послуг.

Отже, управління якістю сучасних туристичних послуг передбачає можливість управління процесами формування та реалізації таких послуг базуючись на визначених критеріїв якості, зважаючи на сучасні умови розвитку галузі ключовим критерієм якості $\epsilon$ безпека. Запропонована модель управління якістю сучасних туристичних послуг передбачає, що підвищення рівня якості обслуговування призводить до підвищення загального рівня якості туристичних послуг та може бути поділена на три основні рівні (найвищий, високий та базовий). 


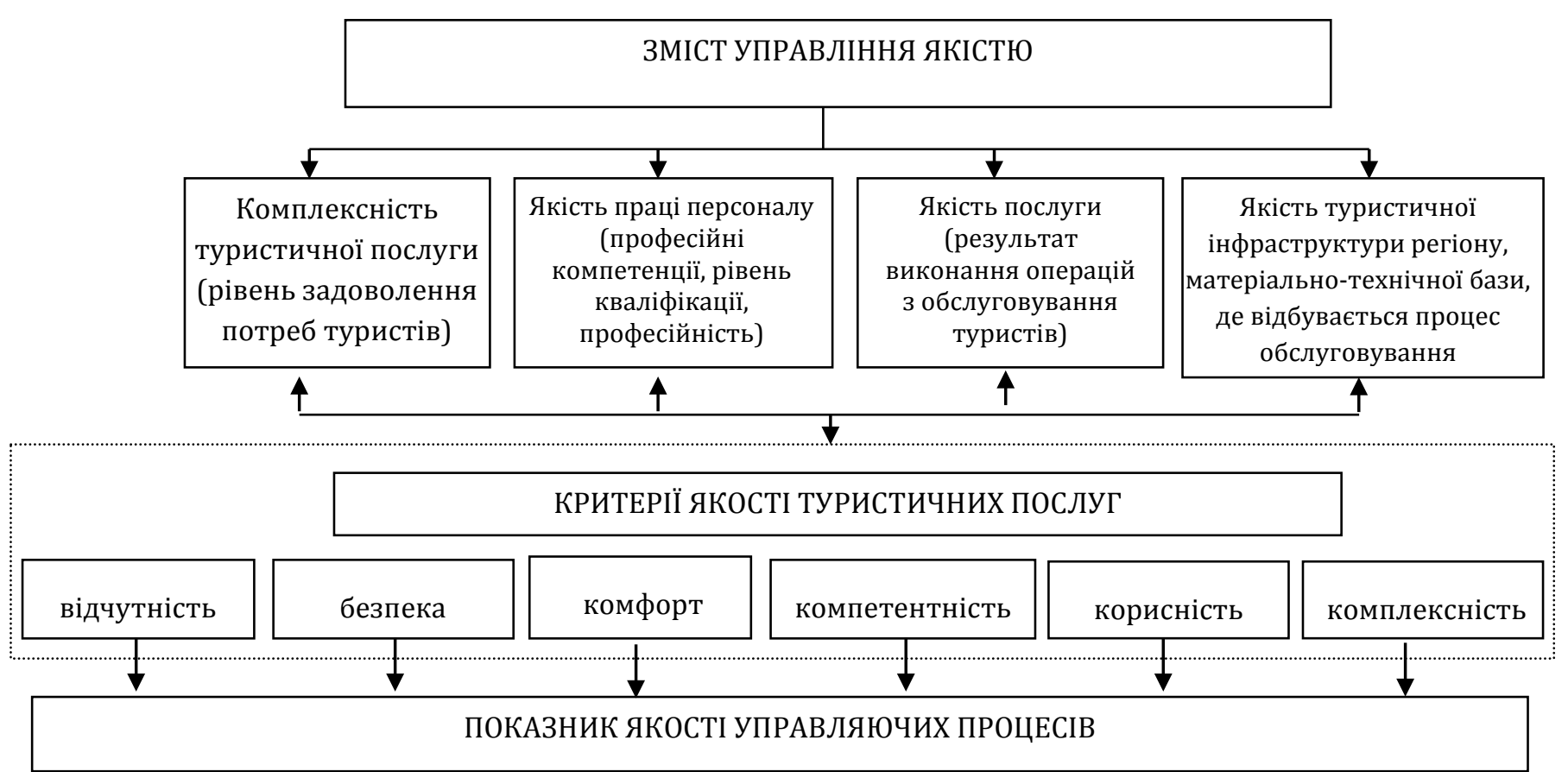

- якість місця, де відбувається процес надання туристичних послуг;

- якість виконання роботи (надання сучасної туристичної послуги);

- якість сучасної туристичної послуги;

- якість визначена рівнем виконання потреб та очікувань туристів (споживача сучасних туристичних послуг)

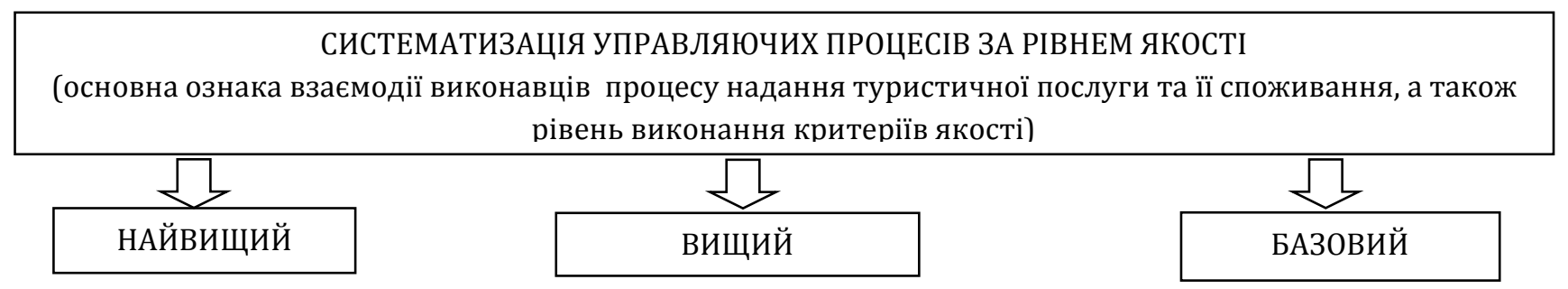

Рис. 2. Модель управління якістю туристичних послуг в регіонах України

\section{ВИСНОВКИ}

Тому, для розвитку туризму в регіоні необхідне запровадження ефективних методів економічного стимулювання. Для вирішення завдань щодо розвитку сфери туристичних послуг України необхідно внести відповідні зміни та доповнення до діючого законодавства 3 питань туризму; здійснити програму створення розгалуженої інфраструктури в галузі, провести реконструкцію матеріальної бази туризму; забезпечити цивілізовані умови щодо перетину кордону (прикордонний, митний контроль); відкрити туристичні представництва в зарубіжних країнах.
Реалізація управлінських заходів дасть змогу посилити темпи розвитку туристичної сфери, дозволить проводити активну загальнодержавну політику в цій важливій складовій економіки України, забезпечити дійову координацію заходів центральних та місцевих органів виконавчої влади, громадських організацій, що сприятиме збільшенню туристичних потоків на внутрішньому ринку туристичних послуг, створенню необхідних умов для швидкого розвитку суміжних галузей, організації нових робочих місць, збільшенню надходжень до бюджетів всіх рівнів. 


\section{References}

Azghaldov H.H. (1994). Obshchye svedenyia o metodolohyy kvalymetryy. Standartы y kachestvo, p. 25

Dyshko O.L. (2016). Formuvannia hotovnosti bakalavriv do profesiinoi vzaiemodii $\quad \mathrm{z}$ spozhyvachamy turystychnykh posluh: dys.kand. ped. nauk: 13.00.04 - teoriia i metodyka profesiinoi osvitnosti. Rivne. 260 p.

Harbera O.Ye. (2010). Orhanizatsiia turystychnoi diialnosti $\mathrm{v}$ systemi svitovoho rynku, Ekonomika ta derzhava, (10). 8689.

Hudyma M.M. (2010). Turystychna posluha: problemy vyznachennia poniattia. Aktualni problemy vdoskonalennia chynnoho zakonodavstva Ukrainy, 23. 126132.

Konakh S. S. (2015). Teoretychni pidkhody do vyznachennia sutnosti poniattia "sfera posluh". Naukovyi visnyk
Mizhnarodnoho universytetu. Seriia: Ekonomika i menedzhment, 12 . Retrieved from: http://nbuv.gov.ua/UJRN/Nvmgu_eim_201 5_12_11

Kotler F. (1998). Marketynh, menedzhment. Pyter Kom, 1998.

Kudla N.Ye. (2012). Menedzhment turystychnoho pidpryiemstva, Kyiv.

Lazibat T. (2005). Poznavanje robe i upravljanje kvalitetom, Sinergija.

Matviichuk L. Yu., \& Tyshchuk I.V. (2017). Silskyi zelenyi turyzm yak faktor rehionalnoho rozvytku: metodolohichnyi aspekt ta praktychnyi dosvid: monohrafiia. RVV Lutskoho NTU.

Tkachenko T.I. (2009). Stalyi rozvytok turyzmu: teoriia, metodolohiia, realii biznesu: monohrafiia. Kyivskyi natsionalnyi torhovelno-ekonomichnyi universytet. 